\title{
The $c$-kit receptor protein in the testis of green frog Rana esculenta: seasonal changes in relationship to testosterone titres and spermatogonial proliferation
}

\author{
Franca Raucci and Maria Maddalena Di Fiore \\ Department of Life Sciences, Second University of Naples, Via Vivaldi 43, 81100 Caserta, Italy \\ Correspondence should be addressed to M M Di Fiore; Email: mariam.difiore@unina2.it
}

\begin{abstract}
The green frog Rana esculenta is a seasonal breeder. The cyclic changes between almost arrested and highly activated spermatogenesis offer an ideal model to study basic mechanisms of spermatogenesis. In this study, we demonstrated, to our knowledge for the first time, $c$-kit receptor positive cells in the testis of this amphibian. The presence of $c$-kit receptor protein was confirmed by western blotting $(\mathrm{Wb})$ analyses carried out in the testis during all the three main phases of the sexual cycle. The antibody recognized a band of about $150 \mathrm{kDa}$ that was correlated with the positive staining in the germinal epithelium. The immunolabelling for $c$-kit receptor, evaluated by immunohistochemistry (IHC), was localized in I and II spermatogonia (SPG), in I and II spermatocytes, in both elongating spermatids and spermatozoa and in the Leydig cells. Furthermore, $c$-kit expression showed a seasonal pattern connected with both testicular and plasma profiles of testosterone during the reproductive cycle. The highest expression of $c$-kit receptor occurred during the reproductive period, when the testis exhibited the maximum concentration of testosterone. In this period, the mitotic activity of germ cell, assessed by both $\mathrm{Wb}$ and IHC analyses for proliferating cell nuclear antigen (PCNA), was intensive. Indeed, during the post-reproductive period, testosterone titres were the lowest and the expression of both PCNA and c-kit receptor protein in the testis, although present, is minor when compared with the reproductive phase. This evidence suggests that cell division can continue sufficiently to accumulate SPG for the next spring, when new germinal cells undergo multiplication. Finally, during the pre-reproductive period, testosterone levels begin to increase and mitotic activity of germinal epithelium is comparably enhanced. These events seem to precede the period of maximum stimulated spermatogonial proliferation, i.e. the reproductive period. These results suggest that the $c$-kit receptor may play a role in germ cell proliferation and provide a basis for future detailed investigation of regulatory factors of the proliferation of SPG.

Reproduction (2007) 133 51-60
\end{abstract}

\section{Introduction}

The c-kit proto-oncogene encodes for a transmembrane tyrosine-kinase receptor (Besmer et al. 1983, Yarden et al. 1987) with homology to receptors for plateledderived growth factor and colony-stimulating factor-1 (Yarden et al. 1987, Chabot et al. 1988, Qiu et al. 1988). $C$-kit is the gene product of the murine white spotting (W) locus (Besmer et al. 1986, Nocka et al. 1989), mutation which leads to defects in haematopoiesis, melanogenesis and gametogenesis (Geissler et al. 1988).

In rodent testis, the $c$-kit expression starts on post-natal day 5 and is restricted to differentiating type $A$ spermatogonia (SPG), type B SPG, primary spermatocytes (SPC; Yoshinaga et al. 1991, Manova et al. 1993, Vincent et al. 1998, Sette et al. 2000) and Leydig cells (Manova et al. 1990, Motro et al. 1991, Rossi et al. 1991). For its exclusive expression, c-kit receptor could be used as a specific marker for these germinal cell populations (Dym et al. 1995, Morena et al. 1996). The c-kit mRNA was found to be expressed at high levels in SPG, and at lower levels in meiotic pachytene SPC (Sorrentino et al. 1991). A truncated version of $c$-kit was detected in spermatids and spermatozoa (SPZ; Albanesi et al. 1996). Moreover, the immunohistochemical analysis demonstrated the presence of c-kit in acrosomial granules of round spermatids and the acrosomial region of SPZ (Sandlow et al. 1996a, 1996b).

In the testis, the ligand of $c$-kit receptor stem cell factor (SCF) is uniquely expressed by Sertoli cells (Motro et al. 1991, Rossi et al. 1991, Tajima et al. 1991, Yan et al. 1999). The signalling cascade involving SCF and c-kitreceptor system has been demonstrated to be indispensable for spermatogenesis and spermatogonial proliferation/differentiation/survival (Vincent et al. 
1998, Blume-Jensen et al. 2000, Sette et al. 2000). Binding of SCF to $c$-kit receptor activates the tyrosine kinase receptor, followed by phosphorinositide 3-kinase and p70 S6 kinase activation to promote spermatogonial cell proliferation (Feng et al. 2000). In addition, i.v. injection of blocking anti-c-kit MAB activated Cdc42associated tyrosine-kinase 2 (ACK2) caused a depletion of differentiating type A SPG (Yoshinaga et al. 1991) with an increased rate of apoptotic death in SPG and in dividing SPC (Packer et al. 1995). In mutant mice, abnormalities of the SCF/c-kit gene expression, such as gene deletions, point mutations, alternative splicing defects, lead to different changes in spermatogenesis (e.g. decreased primordial germ cell migration, decreased in spermatogonial proliferation; for reviews, see Morrison \& Takahashi 1993, Loveland \& Schlatt 1997).

However, the literature has mainly been focused on the localization and on the role of SCF/c-kit system in mice and rodents, species characterized by continuous spermatogenesis. Only recently were $c$-kit receptor positive SPG and SPC found in the testis of a seasonal breeder, roe deer, Capreolus capreolus and the changes of $c$-kit expression correlated to spermatogenetic activity and the cyclic fluctuation of steroid hormones (Roleans et al. 2002). The release of testosterone is known to be a prerequisite for normal sperm production (see, for reviews, Zirkin 1993, Sharpe 1994). On the other hand, SCF is expressed in the testis by Sertoli cells under testosterone stimulation (Mi et al. 2004) and Leydig cells are a target for SCF (Rothschild et al. 2003). The SCF stimulates DNA synthesis in type A SPG cultured in vitro (Rossi et al. 1993, Hakovirta et al. 1999) and the injection of $c$-kit antibodies blocks their proliferation in vivo (Yoshinaga et al. 1991, Packer et al. 1995). Furthermore, there are several lines of in vitro data that indicate $\mathrm{FSH}$ regulates SCF expression in isolated rat Sertoli cells (McLean et al. 2002). In addition, the protein proliferating cell nuclear antigen (PCNA) is essential for the proliferation of SPG. It is also utilized in cell-cycle control through direct interaction with cyclin and cdk complex, where it allows progression through the G1/s boundary (Zhang et al. 1993). For these considerations, PCNA is utilized as an endogenous and molecular marker for mitotic and testicular epithelium proliferation (Chieffi et al. 2000).

Excluding the data reported for mammalian species, there are no studies yet available on $c$-kitreceptor and on its putative involvement in the spermatogenesis of lower vertebrates. Regarding gonadal activity, seasonal breeders offer a good model to study basic mechanisms on the regulation of spermatogenesis without any manipulations. The purpose of this study was to investigate the expression of $c$-kit receptor in the testis of the amphibian Rana esculenta, which exhibits a well-known seasonality of reproduction (Rastogi et al. 1976, 2005, Di Fiore et al. 2005). The selective labelling of SPG to c-kit receptor protein and its expression during the seasonally activated and reduced proliferation could provide information on the time and the role of interrelationships with other factors and cellular activities regulating spermatogenesis. Therefore, to better understand the control mechanisms regulating spermatogenesis, we evaluated the seasonal fluctuations of $c$-kit expression with both testicular and plasma profiles of testosterone during the reproductive cycle. Finally, the expression of $c$-kit receptor is assessed and related to mitotic activity of the testis of $R$. esculenta, tested with both immunolocalization and western blot analyses for PCNA.

\section{Materials and Methods}

\section{Reproductive aspects of sexual cycle in Rana esculenta male}

The green frog $R$. esculenta is a seasonal breeder living in the Mediterranean area. The animals have a body length of about $6.5-7.0 \mathrm{~cm}$ and a body weight of about $8.5-10.5 \mathrm{~g}$. The reproductive cycle of this amphibian begins at the end of 2 nd year of age and includes the transition between high and low activities of the testis. In fact, the processes of reproduction resurge at the beginning of spring, proceed actively through the summer and decline gradually in the winter, decreasing to an almost total quiescence for a short time (Rastogi et al. 1976, 2005, Di Fiore et al. 2005). Briefly, the sexually quiescent frogs emerge in JanuaryFebruary (pre-reproductive period); soon, gonads and secondary sexual characteristics (SSC) start their development and in little time become reproduction functional (March-June, reproductive period). In this period, the frogs mate and eggs are deposited. Then from July to December (post-reproductive period), despite the still favourable temperature and photoperiod, testicular activity gradually declines and SSC regresses. In this period, some SPZ are produced, but there is no spermiation.

Seasonal changes in the weight of the testes reflect the state of spermatogenesis. In fact, the seasonal maximum of testicular weight occurs when the testes are in an advanced stage of spermatogenesis and therefore in reproductive period $(0.30-0.35 \mathrm{~g})$. In post-reproductive period, the testicular weight decreases until $0.21-0.25 \mathrm{~g}$ and the seasonal minimum corresponds to the stage of pre-reproductive period $(0.14-0.19 \mathrm{~g})$.

\section{Animals}

Taking into account the reproductive characteristics, adult males of $R$. esculenta were captured in the countryside of Caserta (Italy) during the pre-reproductive (JanuaryFebruary), reproductive (March-June) and post-reproductive (October-December) phases. To evaluate a possible stressing cause that can impair the reproductive processes of male frogs, some animals were killed in the field and the others were transferred to a laboratory terrarium with a photothermal regimen consistent with the period of the year. They were fed on mealworms and Drosophila fruit flies ad libitum. Mortality rates were low $(<5 \%)$. 
The technical procedures illustrated below have been carried out either on group of field animals or on group of animals captured and transferred in laboratory terrarium. No differences have been registered between two groups.

\section{Collection of samples}

Soon after capture, animals for each phase of the reproductive cycle were anaesthetized by immersion in a ratio of 1:1000 tap water solution of MS-222 (tricaine methylsulphonate; Sigma). Blood samples were centrifuged at $800 \mathrm{~g}$ for $15 \mathrm{~min}$ and the resulting plasma was stored at $-80{ }^{\circ} \mathrm{C}$ for testosterone assay as reported below. The testes were rapidly dissected out. From each animal, one testis was frozen in liquid nitrogen for testosterone assay and western blot analyses, while the other testis was fixed by immersion in Bouin's fluid and processed for histology and immunohistochemistry (IHC).

The methods of capture and dissection and the captive rearing conditions were in accordance with Italian law (D. L.vo 116/92) and authorized by the appropriate Italian government administrative office (Servizio Veterinario della A.S.L. 44, Prot. Vet. 22/95).

\section{Protein extract preparation}

A pool of three frozen frog testes coming from three different animals were homogenized directly into lysis buffer containing $5 \mathrm{mM}$ Tris- $\mathrm{HCl}, 150 \mathrm{mM} \mathrm{NaCl}, 1 \mathrm{mM}$ EDTA, $1 \mathrm{mM}$ EGTA, $10 \%$ glycerol, $1 \%$ Triton $\mathrm{X}-100,1 \mathrm{mM}$ phenylmethylsulphonyl fluoride, $1 \mu \mathrm{g}$ leupteptin, $0.5 \mathrm{mM}$ sodium orthovanadate, $20 \mathrm{mM}$ sodium pyrophosphate and clarified by centrifugation at 14000 r.p.m. for $10 \mathrm{~min}$. Protein concentrations were estimated using a modified Bradford assay (Bio-Rad). This procedure has been carried out for all the three phases of the sexual cycle.

\section{Western blot analysis}

Forty micrograms of proteins were boiled in Laemmli buffer for 5 min before electrophoresis. The sample was subjected to SDS-PAGE ( $10 \%$ polyacrylamide) under reducing conditions. After electrophoresis, proteins were transferred to nitrocellulose membrane (Immobilion Millipore Corporation, Bedford, MA, USA); completeness of transfer was assessed using prestained protein standards (Bio-Rad). The membrane was treated for $2 \mathrm{~h}$ with blocking solution (TBS/T: $5 \%$ nonfat powdered milk in $25 \mathrm{mM}$ Tris $(\mathrm{pH} 7.4) ; 200 \mathrm{mM} \mathrm{NaCl} ; 0.5 \%$ Triton X-100) and was incubated overnight with rabbit-anti $c$-kit receptor antibody (Santa Cruz, CA, USA) diluted in the ratio of 1:500. After washing with the TBS/T and TBS, membrane was incubated with a horseradish peroxidase-conjugated secondary antibody (1:2000; Chemicon, Temecula, CA, USA) for $60 \mathrm{~min}$ and washed again. Indeed, for PCNA detection, a mouse MAB against recombinant PCNA
(Dako Corp., Hamburg, Germany) diluted in the ratio of 1:2000 was used. Then the membranes were incubated for $60 \mathrm{~min}$ with the anti-mouse peroxidase conjugated (1:5000; Chemicon). Reactions were detected using the ECL system (Amersham Life Science).

The quantification of the bands was obtained by SCAN densitometry. Data are expressed as percentage relative to the maximum value obtained for reproductive period (taken as 100\%). The protein levels were determined and quantified in three separate determinations.

\section{Immunohistochemical localization of $c$-KIT receptor}

To investigate the presence of $c$-kit receptor protein in the germinal epithelium of testis, $c$-kit immunolabelling was carried out. Five randomly chosen sections of the testis, for each frog from each phase of the sexual cycle (three frogs for phase), were examined. Testicular sections fixed in Bouin's solution and embedded in paraffin wax were used. The slides were washed in PBS $0.1 \mathrm{M}(\mathrm{pH}$ 7.4) for $15 \mathrm{~min}$, treated with $3 \% \mathrm{H}_{2} \mathrm{O}_{2}$ for 45 min to inhibit endogenous peroxidase and rinsed in PBS. The slides were then incubated in the blocking solution containing $20 \%$ normal goat serum (Sigma) with 10\% BSA in PBS for $1 \mathrm{~h}$ at room temperature. After blocking, the slides were rinsed in PBS-BSA $10 \%$ and incubated overnight with polyclonal rabbit anti-c-kit antibody (1:200; Santa Cruz). After three rinses in PBS-BSA $10 \%$, the slides were incubated sequentially with biotinylated goat anti-rabbit antibody (1:500; Sigma) diluted in PBS-BSA 10\% and streptavidin $(1: 200$, Pierce, IL, Rockford, USA). Bound antibody was visualized using 3,3'-diaminobenzidine tetrahydrochloride solution (Dako Corp.) according to the manufacturer's instructions. Sections were counterstained with haematoxylin, dehydrated, mounted and visualized by light microscope.

The scoring of immunoreaction was performed on five randomly chosen sections from each animal testis on the total of five different fields for each slide.

\section{Immunohistochemical localization of PCNA protein}

To evaluate germ cells, the PCNA IHC was performed according to a recent study reported by Raucci et al. (2004). Serial deparaffinized sections of frog testes were sequentially incubated in normal goat serum (1:20; Sigma) for $45 \mathrm{~min}$ to reduce undesired background staining, primary antiserum (monoclonal mouse antiPCNA diluted in the ratio of 1:400 with 10\% BSA; Dako Corp.) overnight at $4{ }^{\circ} \mathrm{C}$ in a dark moist chamber, biotinylated secondary antibody (goat anti-mouse IgG diluted in the ratio of 1:500; Sigma), and streptavidin (1:200; Pierce). The immunopositivity was visualized by exposure to 3,3'-diaminobenzidine tetrahydrochloride in Tris buffer (Dako Corp.). Sections were mounted with a synthetic medium. 


\section{Controls}

Specificity of immunostaining for both c-kit receptor and PCNA was determined by (a) omission of primary antiserum, (b) substitution of the primary antiserum with $0.1 \mathrm{M}$ PBS or no immune serum (1:200) and (c) primary antiserum preabsorbed overnight with synthetic antigen (only for c-kit receptor). These controls completely eliminated immunostaining.

\section{Histology}

After dissection, frog testes were rapidly removed and fixed in Bouin's fluid for $48 \mathrm{~h}$ at room temperature. The fixative was then extracted with $70 \%$ ethanol and the tissues were embedded in paraffin wax. The histological exam of the testes was carried out in deparaffinized sections $(7 \mu \mathrm{m})$, rehydrated and stained with haematoxylin and eosin reaction, as described in Mazzi (1977).

\section{Testosterone assays in plasma and testis}

Testosterone determinations in the plasma were conducted utilizing the Enzyme Immunoassay Kits (Adaltis, Bologna, Italy). The following limits of detection were sensitivity $50 \mathrm{pg} / \mathrm{ml}$ (intra-assay variability $4.0 \%$, interassay variability $9.0 \%)$. Plasma samples $(100 \mu \mathrm{l})$ were vortexed with ethyl ether $(1: 10, v / v)$ for $5 \mathrm{~min}$ and centrifuged at $3000 \mathrm{~g}$ for $10 \mathrm{~min}$. The upper phase (ethyl ether) was transferred to a glass tube. Two extractions were performed. The pooled ether phases were left to evaporate on a hot plate at $40-50{ }^{\circ} \mathrm{C}$ under a hood. The residue was dissolved in a $0.5 \mathrm{ml}$ sodium phosphate buffer $0.05 \mathrm{M}(\mathrm{pH} 7.5)$, containing BSA at a concentration of $10 \mathrm{mg} / \mathrm{ml}$, and then utilized for the assay. Tissue samples (testis) were homogenized in the ratio of 1:10 (w/v) with distilled water. The homogenate was then mixed vigorously with ethyl ether $(1: 10, v / v)$ and the ether phase was withdrawn after centrifugation at $3000 \mathrm{~g}$ for $10 \mathrm{~min}$. Three extractions were performed. Pooled ether extracts were dried and then utilized for testosterone immunoassay as previously reported. Testosterone recovery was $85 \%$ from plasma and $80 \%$ from tissues.

\section{Statistical analysis}

Data were compared by ANOVA followed by Duncan's test for multi-group comparison and the Student's $t$-test for between-group comparison. All data were expressed as mean \pm s.D. The level of significance was taken at $P<0.01$ and $P<0.05$.

\section{Results}

The results presented below refer to the animals captured and transferred in laboratory terrarium.

\section{Expression of c-kit receptor protein during the seasonal cycle}

The $c$-kit receptor protein was characterized by western blot and the specific band of about $150 \mathrm{kDa}$ was detected during the annual cycle with a different expression status (Fig. 1). Strong expression of $c$-kit receptor was present in the reproductive period (Fig. 1, lane 2). By contrast, during the pre- and post-reproductive periods, the testis showed a lower expression of $c$-kit(Fig. 1, lanes 1 and 3 respectively).

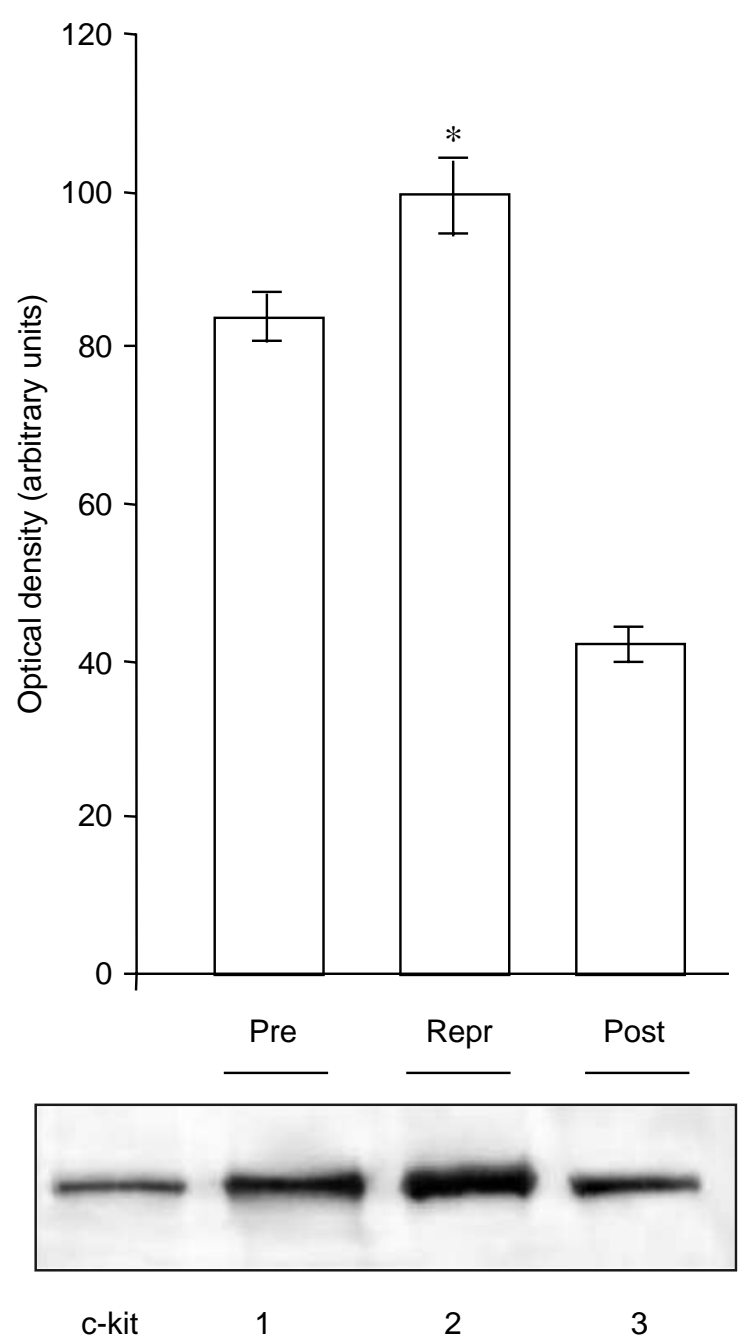

Figure 1 Western blot detection of $c$-kit receptor protein in testicular extract of Rana esculenta during the sexual cycle. Protein ( $40 \mu \mathrm{g} / \mathrm{lane})$ was resolved by SDS-PAGE, transferred to nitrocellulose membrane and then incubated with antibody raised against c-kit receptor protein. A specific band of about $150 \mathrm{kDa}$ was observed by comparison with co-migrating size markers (Bio-Rad). The amount of $c$-kit receptor protein was quantified by densitometry using the SCAN program. The quantification of the data is shown in the histogram. Data are expressed as percentage relative to the maximum value obtained for reproductive period (taken as 100\%). The values shown represent the mean of three separate determinations. Each determination came from a pool of three testes of three different frogs. Error bars represent mean \pm s.D. 1, prereproductive; 2 , reproductive; 3 , post-reproductive. 


\section{C-KIT receptor immunohistochemistry}

The immunohistochemical detection of $c$-kit was carried out on serial slides of testis of green frog $R$. esculenta and revealed the presence of this receptor throughout the annual cycle (Fig. 2). The cytological elements of germinal epithelium show a positive reaction localized in both plasma membrane and cytoplasm. They were mainly I and II SPG, I and II SPC, elongating spermatids and SPZ. Among the somatic cells, Leydig cells also reacted with the $c$-kit receptor antibody (Fig. 2). The intensity of immunolabelling for $c$-kit receptor protein varied depending on the phase of the reproductive cycle. In the reproductive phase (Fig. 2C), the positivity was higher than the pre- (Fig. 2B) and post-reproductive (Fig. 2D) phases. The antibody used for $c$-kit detection was subjected to immunopreabsorption, revealing that the labelling was totally blocked by preincubation with the cognate peptide (Fig. 2A).

Figure 3 shows the immunopositivity of different cytological elements of the testis during the sexual cycle. In the reproductive period, strong $c-k i t$ positive staining was detected in I SPG (Fig. 3B 1 ); the immunopositivity continued to be seen on I SPG at the pre- (Fig. $\left.3 \mathrm{~A}_{1}\right)$ and post-reproductive (Fig. $3 \mathrm{C}_{1}$ ) periods, but its intensity was less than the reproductive phase. In the pre-reproductive period, II SPG were slightly reacted with the $c$-kit receptor antibody (Fig. $3 \mathrm{~A}_{2}$ ). In the reproductive and postreproductive periods, II SPG were intensely positive (Fig. $3 \mathrm{~B}_{2}$ and $\mathrm{C}_{2}$ respectively). Moreover, the staining of I and II SPC of pre-reproductive testis (Fig. $3 \mathrm{~A}_{3}$ and $\mathrm{A}_{4}$ respectively) was less intense than the reproductive (Fig. $3 \mathrm{~B}_{3}$ and $\mathrm{B}_{4}$ respectively) and post-reproductive periods (Fig. $3 C_{3}$ and $C_{4}$ respectively). Strong immunopositivity can be seen also in both elongating spermatids and SPZ during reproductive period (Fig. $3 \mathrm{~B}_{5}$ ), although it decreases in post-reproductive period (Fig. $3 \mathrm{C}_{5}$ ). In the prereproductive period, the reaction in SPZ is the lowest observed during all the phases of the sexual cycle (Fig. 3 $\mathrm{A}_{5}$ ).

\section{Annual profile of testosterone level and histology}

Figure 4 reports the seasonal fluctuation of testosterone levels detected in testis and plasma of green frog $R$. esculenta during the reproductive cycle. In all the major phases of the sexual cycle, substantial amounts of testosterone were found in both testicular extracts and plasma. The androgen level showed significant variation depending on the phase of reproductive cycle and reaching its higher content during the reproductive period $(115 \pm 8.0 \mathrm{ng} / \mathrm{ml}$ testis and $17.4 \pm 1.5 \mathrm{ng} / \mathrm{g}$ plasma respectively). In the pre- and, particularly, post-reproductive periods, the testosterone content detected was significantly lower $(48.6 \pm 2.5 \mathrm{ng} / \mathrm{g}$ testis, $7.5 \pm 0.7 \mathrm{ng} / \mathrm{ml}$ plasma and $25.3 \pm 1.4 \mathrm{ng} / \mathrm{g}$ testis, $2.5 \pm 0.4 \mathrm{ng} / \mathrm{ml}$ plasma respectively) than the reproductive period $(P<0.01)$. Figure 4 also reports the modification of germinal epithelium of testis through the sexual cycle. The testis of green frog
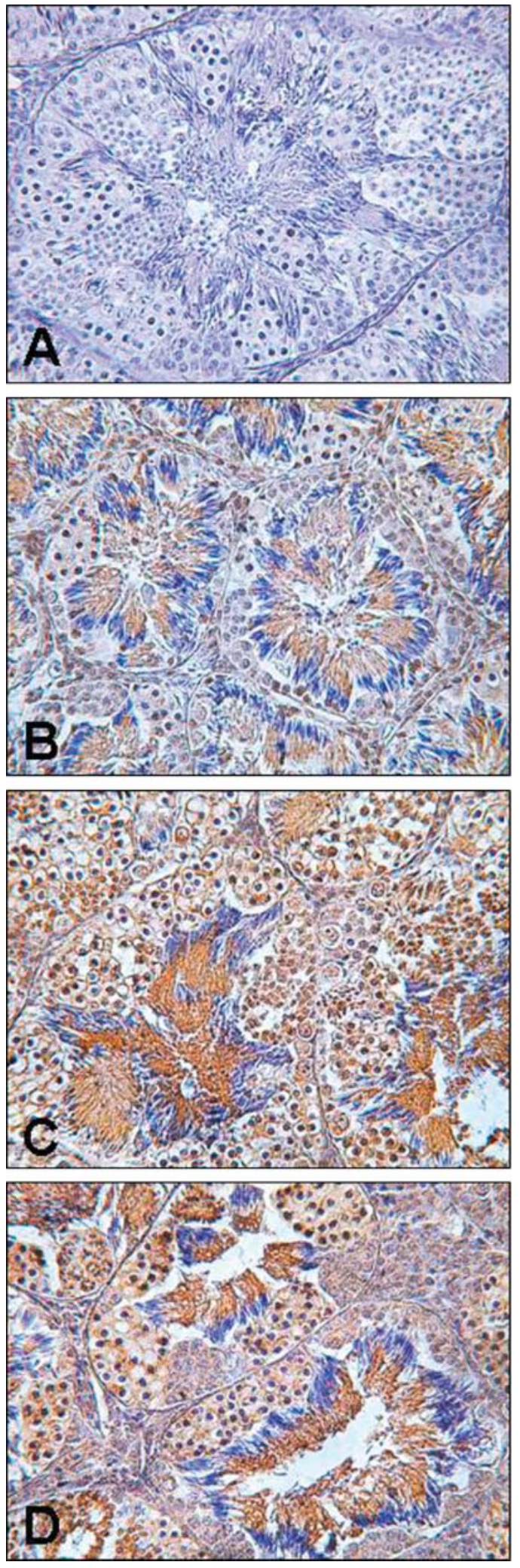

Figure 2 Immunohistochemical detection of $c$-kit receptor positive cells in seminiferous ampoules of Rana esculenta during pre-reproductive $(B)$, reproductive $(\mathrm{C})$ and post-reproductive $(\mathrm{D})$ periods. Negative control, made by primary antiserum pre-absorbed overnight with synthetic antigen $(A) .(\times 500)$. 


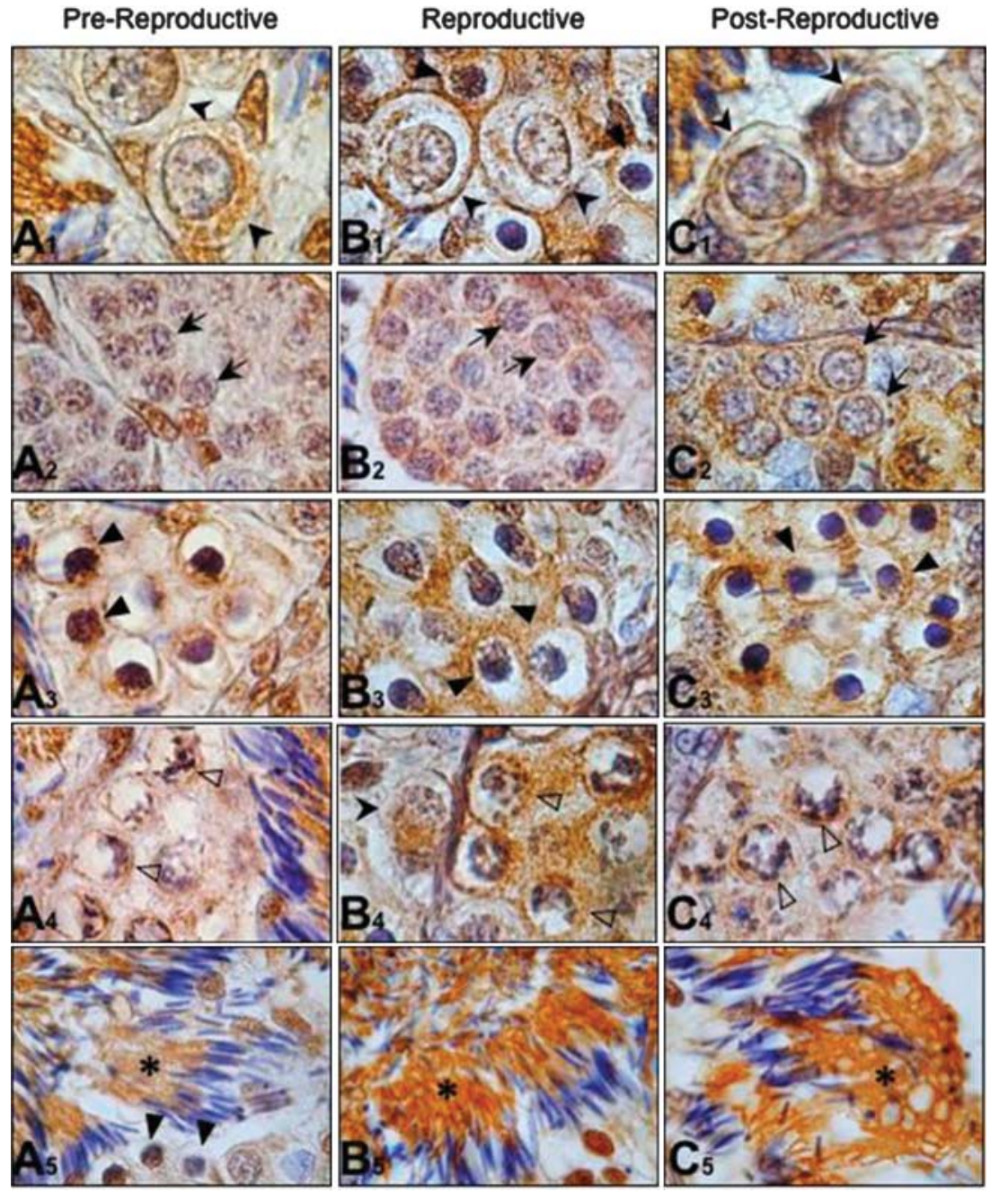

Figure 3 Immunohistochemistry for $c$-kit receptor protein in the testis of Rana esculenta during the sexual cycle. $A_{1}-A_{5}=$ pre-reproductive period; $B_{1}-B_{5}=$ reproductive period; $C_{1}-C_{5}=$ postreproductive period. Arrowhead, I SPG; arrow, II SPG; $\Delta$, I SPC; $\triangle$, II SPC; asterisk, spermatozoa $(\times 1000)$.
$R$. esculenta shows a cystic pattern, i.e. the germ cells proliferate in coordinated clusters enclosed in membranous cyst walls (ampoules). In the pre-reproductive period, seminiferous ampoules of testis contained predominantly I and II SPG. Although I and II SPC and SPT were present, their number was low because they underwent degeneration. Some SPZ were present in the lumen. In the reproductive period, testicular epithelium contained the maximal number of I SPG and appeared highly differentiated. The highest number of II SPG was present in the cysts and their massive transformation into I SPC occurred; II SPC was also evident and the lumen was full of SPZ. In the post-reproductive period, high numbers of cysts still contained I and II SPC although their decrease was closely associated with the formation of SPT. Not many SPZ were present in the lumen.

\section{Expression of PCNA protein during the seasonal cycle}

Western blot analyses used for PCNA determination showed that testis contained a specific band of 36 about
kDa found during all the phases of the sexual cycle (Fig. 5). The expression of PCNA underwent fluctuation depending on the phase of the cycle. A higher expression of PCNA was seen in the reproductive period (Fig. 5, lane 2) than pre- and post-reproductive periods (Fig. 5, lanes 1 and 3 respectively).

\section{PCNA immunohistochemistry}

The presence of PCNA was examined in frog testes during the sexual cycle. IHC analyses were performed on serial sections and revealed the presence of PCNA protein in both cytoplasm and nucleus of I and II SPG and in the nuclei of SPC, while II SPC and spermatids remained negative.

In the pre-reproductive period, seminiferous ampoules of the testis showed fair immunoreactive material in I SPG multiplying. Moreover, II SPG and I SPC were moderately positive to PCNA (Fig. 6A). In the reproductive period, testicular epithelium showed the highest intensity of immunoreaction for PCNA. The positivity 
Pre-reproductive
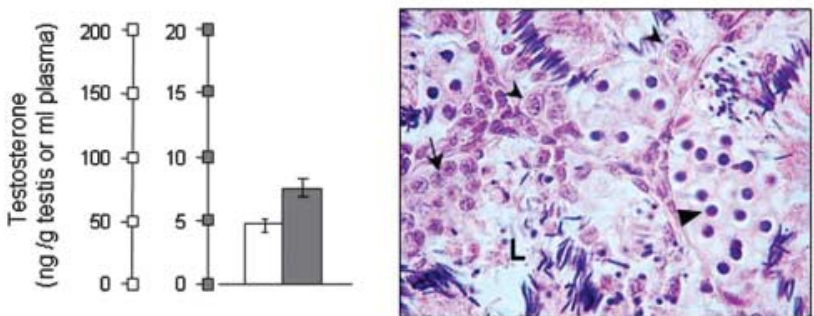

Reproductive
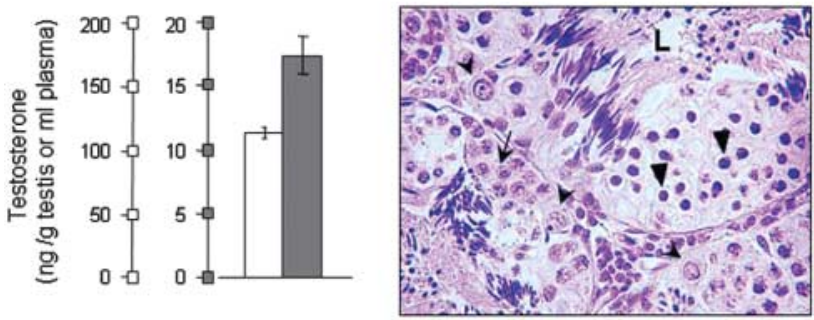

Post-reproductive
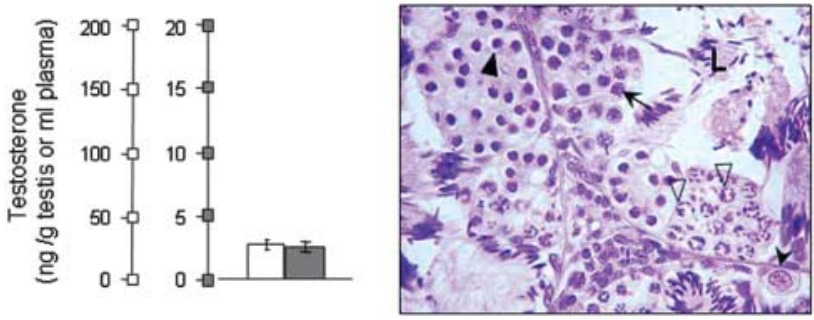

Figure 4 Seasonal changes in testosterone content detected in both testis $(\square)$ and plasma $(\square)$ of green frog Rana esculenta, during the reproductive cycle. Results are expressed as mean \pm s.D. obtained from five individual animals. Histological sections of testis of Rana esculenta during pre-reproductive, reproductive and post-reproductive periods. Arrowhead, I SPG; arrow, II SPG; $\boldsymbol{\Delta}$, I SPC; $\triangle$, II SPC; L, lumen. haematoxylin/eosin $(\times 500)$.

was localized in I and II SPG and in I SPC (Fig. 6B). In the post-reproductive period, the immunopositivity for PCNA was contained in identical cell types observed in the other two periods; but in this phase, the intensity of the immunolabelling was visibly lower than the pre- and post-reproductive phases (Fig. 6C).

\section{Discussion}

This study ascertained the presence of the $c$-kit receptor in the testis of the green frog $R$. esculenta during the reproductive cycle. It also shed light on unmanipulated basic mechanisms regulating testicular activity in this model of amphibian seasonal breeders.

Results of western blot analysis demonstrated the expression of $c$-kit receptor in the testis of this species and indicated the polyclonal antibody recognized a single protein of $\sim 150 \mathrm{kDa}$. Two forms of $c$-kit receptor with an apparent molecular size of 124 and $160 \mathrm{kDa}$ have been detected in the rat testis (Dym et al. 1995) and

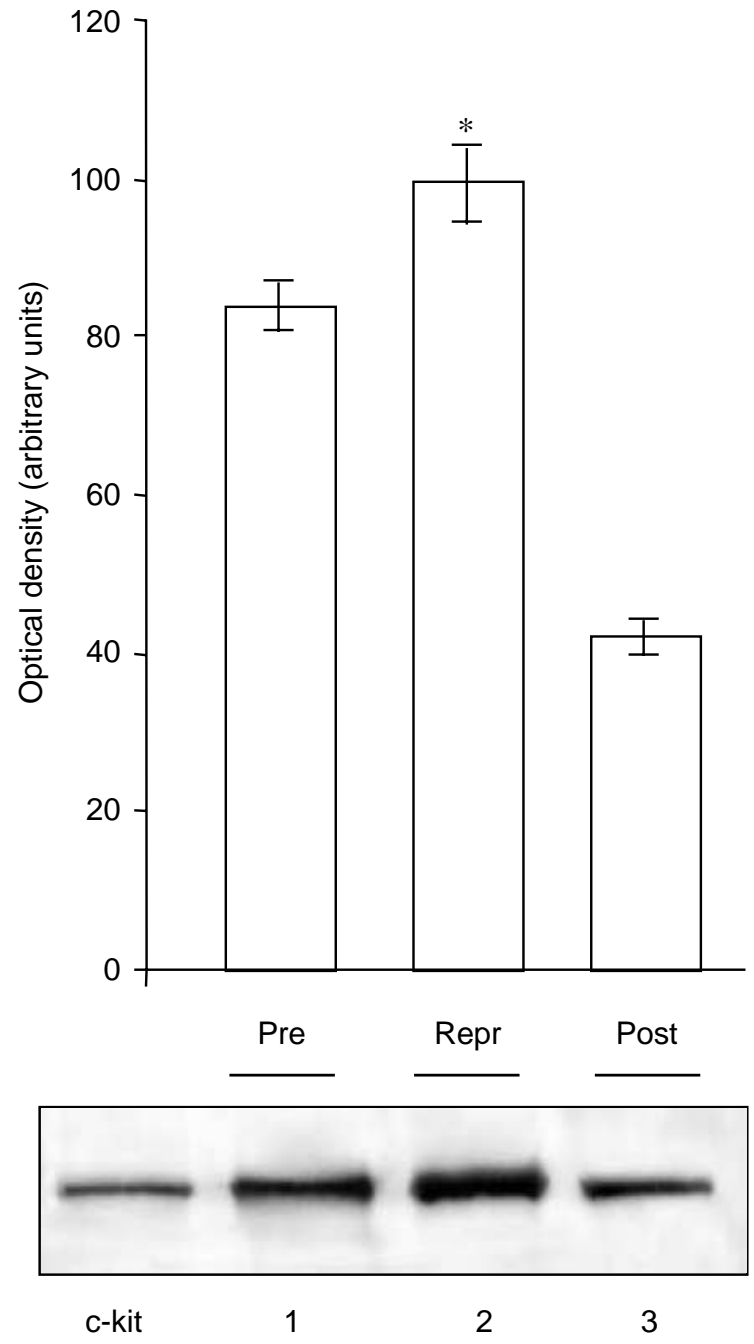

Figure 5 Western blot analyses of PCNA protein in testicular extract of Rana esculenta during the sexual cycle. Protein ( $40 \mu \mathrm{g} / \mathrm{lane})$ was resolved by SDS-PAGE, transferred to nitrocellulose membrane and incubated with antibody raised against PCNA protein. A specific band of about $36 \mathrm{kDa}$ was observed by comparison with co-migrating size markers (Bio-Rad). The amount of PCNA was quantified by densitometry using the SCAN program. The quantification of the data is shown in the histogram. Data are expressed as percentage relative to the maximum value obtained for reproductive period (taken as 100\%). The values shown represent the mean of three separate determinations. Each determination came from a pool of three testes of three different frogs. Error bars represent mean \pm s.D. 1, pre-reproductive; 2, reproductive; 3 , post-reproductive.

results indicate that the $124 \mathrm{kDa}$ protein could be an immature protein, while the $160 \mathrm{kDa}$ protein is the mature fully glycosylated form of c-kit (Nocka et al. 1989). On the other hand, there may be three isoforms of c-kit receptor proteins in mouse sperm, one isomatic isoform $(33 \mathrm{kDa})$ that is expressed in the sperm tail and two testis-specific isoforms ( 150 and $48 \mathrm{kDa}$ ) that are expressed in the acrosomial region (Feng et al. 1998). It is also possible that the $33 \mathrm{kDa}$ protein is generated by 


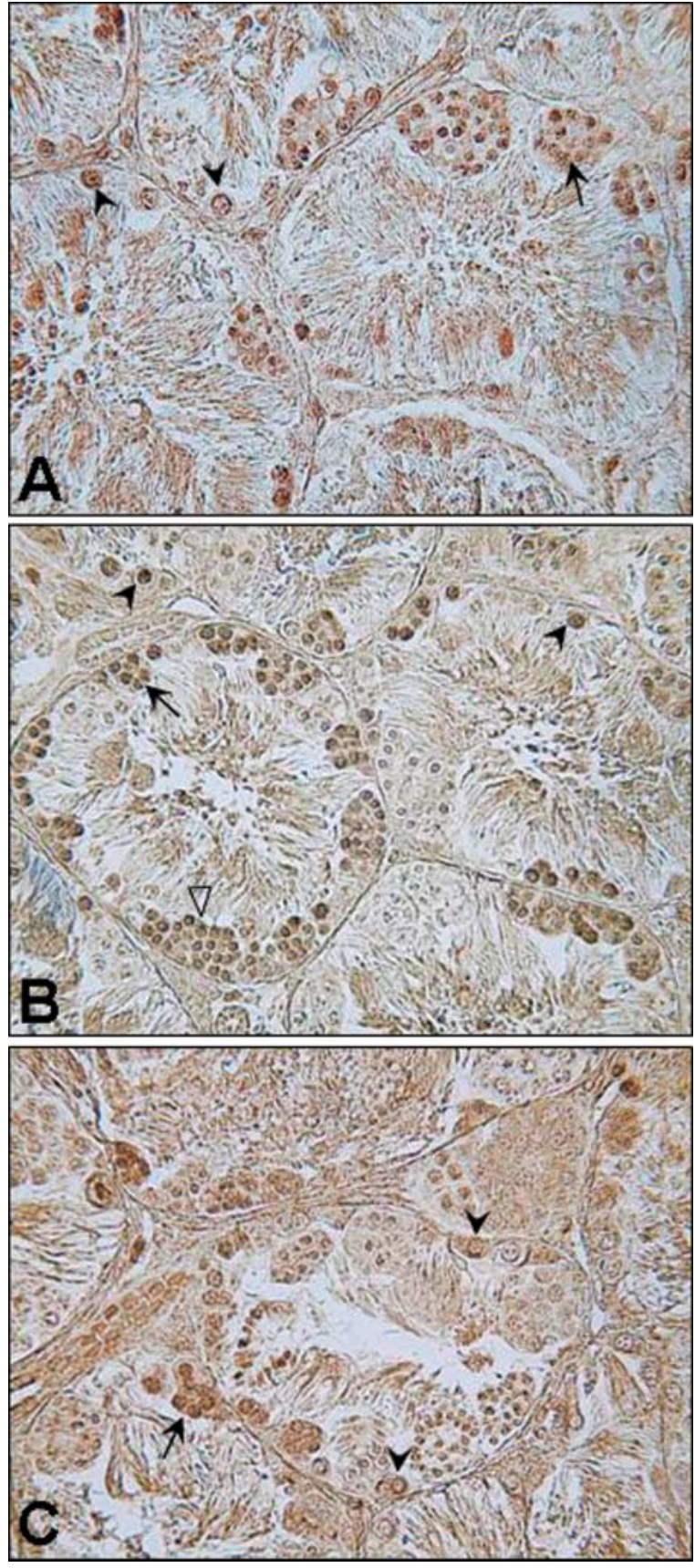

Figure 6 Immunohistochemistry for PCNA in the testis of Rana esculenta showing a positive reaction in the cytoplasm and the nucleus of I (arrowheads) and II (arrow) SPG and I SPC (open arrow) during the pre-reproductive $(\mathrm{A})$, reproductive $(\mathrm{B})$ and post-reproductive (C) periods $(\times 500)$.

proteolytic cleavage of $150 \mathrm{kDa} c-k i t$ receptor protein during sample preparation or represents a cross-reaction with a somatic protein. In addition, more recent reports propose that the binding of c-kit ligand to receptor induces c-kit dimerization autophosphorylation so that the c-kit receptor is present as both membraneassociated and soluble (Kierszenbaum 2006).
Using a rabbit polyclonal anti-c-kit, we also carried out the IHC for $c$-kit receptor protein in the germinal epithelium of testis. The finding showed that the $c$-kit receptor protein was predominantly localized on the membrane of I and II SPG, I and II SPC, elongated spermatids and SPZ in all the phases of the yearly cycle. Particularly, strong c-kit positivity staining was observed in the testis during the reproductive period, when the spermatogenesis was strongly activated (Rastogi et al. 1976, 2005, Di Fiore et al. 2005). Since the antibody was raised against the c-terminal domain of the $c$-kit receptor, which is known to be the intracellular domain of the receptor (Yarden et al. 1987, Qiu et al. 1988), it may be assumed that the signal was membrane associated (possibly intercellular). Previously, Yoshinaga et al. (1991) showed high expression of $c$-kit receptor in mouse testis in type $\mathrm{A}$ SPG, low expression in intermediate and type B SPG and in the earliest preleptotene SPC. Later, it was demonstrated that the c-kit receptor also is expressed in the acrosomal granules of round spermatids and the acrosomic region of SPZ (Albanesi et al. 1996, Sandlow et al. 1996a, 1996b, 1997, Feng et al. 1998), suggesting the receptor's involvement in some crucial step(s) for capacitation and/or the acrosome reaction (Feng et al. 2005).

C-kit receptor is a conservative molecule and the cDNA has been isolated in lower vertebrates, such as chicken (Sasaki et al. 1993), Xenopus (Baker et al. 1995, Kao \& Bernstein 1995) and zebrafish (Parichy et al. 1999). Addition of human recombinant SCF to newt testicular organ cultures stimulates the SPG proliferation and they progressed to the seventh generation, the penultimate stage before the primary spermatocyte stage. However, the SPG do not differentiate into SPC and do not die by apoptosis (Abè et al. 2002). These data are consistent with the previous results in mice where added SCF to cultured male germ cells stimulates DNA synthesis in type A SPG (Rossi et al. 1991, Hakovirta et al. 1999). Moreover, the i.v. injection of ACK-2, a MAB that blocks the binding of SCF to $c$-kit, causes a loss of differentiating type A SPG, but has no effect on the transition of intermediate SPG to type B SPG or primary SPC (Yoshinaga et al. 1991).

The expression of $c$-kit receptor protein in the testis of frog $R$. esculenta evaluated by western blot data parallels cyclic changes of germinal epithelium and is well correlated with both plasma and testicular levels of testosterone. In fact, the highest expression of c-kit receptor occurred during the reproductive period, when seminiferous ampoules were completely differentiated and both testicular and plasma content of $\mathrm{T}$ was at the maximum peak. Instead, during the pre- and postreproductive periods, the expression of $c$-kit as well as testosterone levels was lower. The fluctuation of $c$-kit receptor protein was also correlated to mitotic activity of the testis, evaluated by both western blot and 
immunohistochemical detection of PCNA during the sexual cycle. In the reproductive period, in fact, PCNA expression was the highest as well as the immunoreactivity of germinal epithelium to this mitotic factor. These findings suggest that c-kit receptor could be implied in the proliferation of the germinal epithelium of $R$. esculenta. On the another hand, Roleans et al. (2002) observed that in roe deer, Capriolus capriolus, the testis showed a specific pattern of spermatogonial c-kit receptor positive cell, in relation to testosterone levels.

In the amphibian $R$. esculenta, the highest level of testosterone during the reproductive phase is beneficial for spermatogenesis and the development and maturation of the androgen-dependent target organ (Rastogi et al. 1976, Delrio et al. 1980, Varriale \& Serino 1994, Di Fiore et al. 2005). On the other hand, Raucci et al. (2004) demonstrated that the increase of testosterone titres causes and increase of seminiferous ampulae area and their spermatid and sperm contents. In addition, in vitro experiments carried out on cultured testicular germ cells of embryonic chickens demonstrated that the testosterone treatment induced stronger $c-k i t$ and PCNA expressions, indicating that this hormone promoted testicular germ cell proliferation probably through indirect effects on Sertoli cells (Mi et al. 2004). Furthermore, in cultured cells of mouse SPG, SCF enhanced $c$-kit expression of type A SPG by stimulating their progression into the mitotic cell cycle (Dolci et al. 2001).

In our study, light microscopy revealed that Leydig cells show a $c$-kit immunopositive reaction. c-kit localization in Leydig cells has already been known (Sandlow et al. 1996a, 1996b, 1997) and its expression is connected to a paracrine regulation of Leydig cell steroidogenetic function (Rothschild et al. 2003). However, soluble SCF might participate in the regulation of formation of Leydig cell population during testicular development. These data indicate that there is a reciprocal control between SCF production by Sertoli cells, testosterone production by Leydig cells and c-kit expression (Yan et al. 2000).

In conclusion, our study demonstrates for first time in non-mammalian vertebrate testis, the presence of $c$-kit receptor protein and suggests a direct subtle cooperation between the testosterone and the expression of $c-k i t$ during the seasonal cycle of $R$. esculenta. In addition, mitotic activity of germinal epithelium is well correlated with plasma and testicular levels of the androgen hormone.

As demonstrated in mammals, in $R$. esculenta, c-kit could play a pivotal role in the timing of the steps of the spermatogenesis. Future investigations should address the precise function of $c$-kit receptor in the processes of spermatogenesis. This will open further investigation on the involvement of regulatory factors in the proliferation of the SPG.

\section{References}

Abè K, Jin Y, Yamamoto T \& Abè S-I 2002 Human recombinant stem cell factor promotes spermatogonial proliferation, but not meiosis initiation in organ culture of newt testis fragments. Biochimical and Biophysical Research Communications 294 695-699.

Albanesi C, Geremia R, Giorgio M, Dolci S, Sette C \& Rossi P 1996 A cell- and developmental stage-specific promoter drives the expression of a truncated c-kit protein during mouse spermatid elogation. Development 122 1291-1302.

Baker CV, Sharpe CR, Torpey NP, Heasman J \& Wylie CC 1995 A Xenopus c-kit-related receptor tyrosine kinase expressed in migrating stem cells of lateral line system. Mechanisms of Development $\mathbf{5 0}$ 217-228.

Besmer P, Snyder HW, Murphy JE, Hardy WD \& Parodi A 1983 The Perodi-Irgens feline sarcoma virus and simian sarcoma virus have homologous oncogene, but, in different contents of the viral genome. Journal of Virology 46 606-613.

Besmer P, Murphy JE, George PC, Qiu F, Bergold PJ, Lederman L, Snyder HW, Brodeur D, Zuckerman EE \& Hardy WD 1986 A new acute transforming feline retrovirus and relationship of its oncogene $\mathrm{v}$-kit with the protein kinase family. Nature 320 415-421.

Blume-Jensen P, Jiang G, Hyman R, Lee KF, O'Gorman S \& Hunter T $2000 \mathrm{Kit} / \mathrm{stem}$ cell factor-receptor induced activation of phosphatidylinositol 3'-kinase is essential for male fertility. Nature Genetics 24 157-162.

Chabot B, Stephenson DA, Chapman VM, Besmer P \& Berstein A 1988 The proto-oncogene $c$-kit encoding a transmembrane tyrosine kinase receptor maps to the mouse W locus. Nature 335 88-89.

Chieffi P, Franco R, Fulgione D \& Staibano S 2000 PCNA in the testis of the frog Rana esculenta: a molecular marker of the mitotic testicular epithelium proliferation. General and Comparative Endocrinology 119 11-16.

Delrio G, Citarella F \& d'Istria M 1980 Androgen receptor in the thumb pad of Rana esculenta: dynamic aspects. Journal of Endocrinology 85 279-282.

Di Fiore MM, Chieffi Baccari G, Rastogi RK, Di Meglio M, Pinelli C \& Iela L 2005 Hormonal regulation of secondary sexual characters. In Amphibian Biology, Amphibian Biology, pp 2228-2249. Ed. H Heatwole vol VI. Sydney: Surrey Beatty \& Sons.

Dolci S, Pellegrini M, Di Agostino S, Geremia R \& Rossi P 2001 Signaling through extracellular signal-regulated kinase is required for spermatogonial proliferative response to stem cell factor. Journal of Biological Chemistry 276 40225-40233.

Dym M, Jia M-C, Dirami G, Price JM, Rabin SJ, Mocchetti I \& Ravindranath N 1995 Expression of c-kit receptor and its autophosphorylation in immature rat type A spermatogonia. Biology of Reproduction 52 8-19.

Feng H, Sandlow JI \& Sandra A 1998 The $c$-kit receptor and its possible signaling trasduction pathway in mouse spermatozoa. Molecular Reproduction and Development 49 317-326.

Feng LX, Ravindranath N \& Dym M 2000 Stem cell factor/c-kit up-regulates cyclin D3 and promotes cell cycle progression via the phosphoinositide 3-kinase/p70 S6 kinase pathway in spermatogonia. Journal of Biological Chemistry 275 25572-25576.

Feng HL, Sandlow JL \& Zheng LJ 2005 C-kit receptor and its possible function in human spermatozoa. Molecular Reproduction and Development 70 103-110.

Geissler EN, Ryan MA \& Housman DE 1988 The dominant white spotting (W) locus of the mouse encodes the c-kit proto-oncogene. Cell 55 185-192.

Hakovirta H, Yan W, Kaleva M, Zhang F, Vanttinen K, Morris PL, Soder M, Parvinen M \& Toppari J 1999 Function of stem cell factor as survival factor of spermatogonia and localization of messenger ribonucleic acid in the rat seminiferous epithelium. Endocrinology 140 1492-1498.

Kao KR \& Bernstein A 1995 Expression of Xkl-1, a Xenopus gene related to mammalian $c$-kit, in dorsal embryonic tissue. Mechanisms of Development $\mathbf{5 0} 57-69$. 
Kierszenbaum AL 2006 Tyrosine protein kinases and spermatogenesis: truncation matters. Molecular Reproduction and Development 73 399-403.

Loveland KL \& Schlatt S 1997 Stem cell factor and c-kit in the mammalian testis: lessons originating from mother nature's gene knockouts. Journal of Endocrinology 153 337-344.

Manova K, Nocka K, Besmer P \& Bachvarova RF 1990 Gonadal expression of $c$-kit encode at the $W$ locus of the mouse. Development 110 1057-1069.

Manova K, Huang EJ, Angeles M, De Leon V, Sanchez S, Pronovost SM, Besmer P \& Bachvarova RF 1993 The expression pattern of the $c$-kit ligand in gonads of mice supports a role for the $c$-kit receptor in oocyte growth and in proliferation of spermatogonia. Developmental Biology 157 85-99.

Mazzi V 1977 Manuale di Tecniche Istologiche e Istochimiche, Padova, Italy: Piccin.

McLean DJ, Friel PJ, Pouchnik D \& Griswold MD 2002 Oligonucleotide microarray analysis of gene expression in follicle-stimulating hormone-treated rat sertoli cells. Molecular Endocrinology $\mathbf{1 6}$ 2780-2792.

Mi Y, Zhang C, Xie M \& Zeng W 2004 Effects of follicle-stimulating hormone and androgen on proliferation of cultured testicular germ cells of embryonic chickens. General and Comparative Endocrinology 138 237-246.

Morena AR, Boitani C, Pesce M, de Felici M \& Stefanini M 1996 Isolation of highly purified type A spermatogonia from prepubertal rat testis. Journal of Andrology 17 708-717.

Morrison GK \& Takahashi Y 1993 Steel factor and c-kit receptor: from mutants to a growth factor system. BioEssays 15 77-83.

Motro B, Van Der Kooy D, Rossant J, Reith A \& Bernstein A 1991 Contiguous pattern of $c$-kit and steel expression: analysis of mutations at the W and SI loci. Development 113 1207-1221.

Nocka K, Majumder S, Chabot B, Ray P, Cervone M, Bernstein A \& Besmer P 1989 Expression of $c$-kit gene products in known cellular targets of $\mathrm{W}$ mutations in normal and $\mathrm{W}$ mutant mice-evidence for an impaired $c$-kit kinase in mutant mice. Genes \& Development 3 816-826.

Packer Al, Besmer P \& Bachvarova RF 1995 Kit ligand mediates survival of type A spermatogonia and dividing spermatocytes in postnatal mouse testes. Molecular Reproduction and Development 42 303-310.

Parichy DM, Rawls JF, Pratt SJ, Whitfield TT \& Johnson SL 1999 Zebrafish sparse corresponds to an orthologue of c-kit and is required for the morphogenesis of a subpopulation of melanocytes, but is not essential for hematopoiesis or primordial germ cell development. Development 126 3425-3436.

Qiu FH, Ray P, Brown K, Barker PE, Jhanwar S, Ruddle FH \& Besmer P 1988 Primary structure of $c$-kit: relationship with the CSF-1/PDGF receptor kinase family-oncogenic activation of v-kit involves deletion of extracellular domain and C terminus. EMBO Journal 7 1003-1011.

Rastogi RK, Iela L, Saxena PK \& Chieffi G 1976 The control of spermatogenesis in the green frog Rana esculenta. Journal of Experimental Zoology 196 151-166.

Rastogi RK, Iela L, di Meglio M, Di Fiore MM, D'Aniello B, Pinelli C \& Fiorentino M 2005 Hormonal regulation of reproductive cycles in Amphibians. In Amphibian Biology, Amphibian Biology, pp 2045-2177. Ed. H Heatwole vol VI. Sydney: Surrey Beatty \& Sons.

Raucci F, Assisi L, D'Aniello S, Spinelli P, Botte V \& Di Fiore MM 2004 Testicular endocrine activity is upregulated by D-aspartic acid in the green frog, Rana esculenta. Journal of Endocrinology 182 365-376.

Roleans H, Schneider F, Goritz F, Streich J \& Blottner S 2002 Seasonal changes of spermatogonial proliferation in roe deer, demonstrated by flow cytometric analysis of $c$-kit receptor, in relation to folliclestimulating hormone, luteinizing hormone, and testosterone. Biology of Reproduction 66 305-312.

Rossi P, Albanesi C, Grimaldi P \& Geremia R 1991 Expression of the mRNA for the ligand of $c$-kit in mouse Sertoli cells. Biochemical and Biophysical Research Communications 176 910-914.
Rossi P, Dolci S, Albanesi C, Grimaldi P, Ricca R \& Geremia R 1993 FSH induction of Steel Factor (SLF) mRNA in mouse Sertoli cells and stimulation of DNA synthesis in spermatogonia by soluble SLF. Developmental Biology 155 68-74.

Rothschild G, Sottas CM, Kissel H, Agosti V, Manova K, Hardy MP \& Besmer P 2003 A role for kit receptor signaling in Leydig cell steroidogenesis. Biology of Reproduction 69 925-932.

Sandlow JI, Feng HL \& Sandra A 1996a Expression of $c$-kit and its ligand, stem cell factor, in normal and subfertile human testicular tissue. Journal of Andrology 17 403-408.

Sandlow JI, Feng HL \& Sandra A $1996 b$ Expression of $c$-kit receptor in spermatogenis cells and normal sperm. Journal of Andrology 1724.

Sandlow JL, Feng HL \& Sandra A 1997 Localization and expression of $c$-kit receptor protein in human and rodent testis and sperm. Urology 49 494-500.

Sasaki E, Okamura H, Chikamune T, Kanai Y, Watanabe M, Naito M \& Sakurai M 1993 Cloning and expression of the chicken $c$-kit protooncogene. Gene 128 257-261.

Sette C, Dolci S, Geremia R \& Rossi P 2000 The role of stem cell factor and of alternative $c$-kit gene products in the establishment, maintenance and function of germ cells. International Journal of Developmental Biology 44 599-608.

Sharpe RM 1994 Regulation of spermatogenesis. In The Physiology of Reproduction, 2 edn, pp 1363-1434. Eds E Knobil \& JD Neill, vol 2. New York: Raven Press

Sorrentino V, Giorgi M, Geremia R, Besmer P \& Rossi P 1991 Expression of $c$-kit proto-oncogene in the murine male germ cells. Oncogene 6 149-151.

Tajima Y, Onoue H, Kitamura Y \& Nishimune Y 1991 Biologically active $c$-kit ligand growth factor is produced by mouse Sertoli cell and is defective in SI/d mutant mice. Development 113 1031-1035.

Varriale B \& Serino I 1994 The androgen receptor mRNA is up-regulated by testosterone in both the Harderian gland and thumb pad of the frog, Rana esculenta. Journal of Steroid Biochemistry and Molecular Biology 51 259-265.

Vincent S, Segretain D, Nishikawa S, Nishikawa SI, Sage J, Cuzin F \& Rassoulzadegan M 1998 Stage-specific expression of the Kit receptor and its ligand $(\mathrm{KL})$ during male gametogenesis in the mouse: a Kit-KL interaction critical for meiosis. Development 125 4585-4593.

Yan W, Linderborg J, Suominen J \& Toppari J 1999 Stage-specific regulation of stem cell factor gene expression in the rat seminiferous epithelium. Endocrinology 140 1499-1504.

Yan W, Suominen J \& Toppari J 2000 Stem cell factor protects germ cells from apoptosis in vitro. Journal of Cell Science 113 161-168.

Yarden Y, Kuang WJ, Yang-Feng T, Coussens L, Munemitsu S, Dull TJ, Chen E, Schlessinger J, Francke U \& Ullirch A 1987 Human protooncogene $c$-kit: a new cell surface receptor tyrosine kinase for an unidentified ligand. EMBO Journal 6 3341-3351.

Yoshinaga K, Nishikawa S, Ogawa M, Hayashi S, Kunisada T \& Fujimoto T 1991 Role of $c$-kit in mouse spermatogenesis: identification of spermatogonia as a specific site of $c$-kit expression and function. Development 113 689-699.

Zhang H, Xiong Y \& Beach D 1993 Proliferating cell nuclear antigen and p21 are components of multiple cell cycle kinase complexes. Molecular Biology of the Cell 4 897-906.

Zirkin BR 1993 Regulation of spermatogenesis in the adult mammal: gonadotropins and androgens. In Cell and Molecular Biology of the Testis, pp 166-188. Eds C Desjardins \& LL Ewing. New York: Oxford University Press.

Received 20 October 2005

First decision 14 February 2006

Revised manuscript received 6 November 2006

Accepted 9 November 2006 